Atmos. Chem. Phys., 13, 10081-10094, 2013

www.atmos-chem-phys.net/13/10081/2013/

doi:10.5194/acp-13-10081-2013

(c) Author(s) 2013. CC Attribution 3.0 License.

\title{
Expansion of global drylands under a warming climate
}

\author{
S. Feng ${ }^{1,2, *}$ and $\mathbf{Q}$. Fu ${ }^{1,3}$ \\ ${ }^{1}$ Key Laboratory of Western China's Environmental Systems \& College of Atmospheric Sciences, Lanzhou University, China \\ ${ }^{2}$ School of Natural Resources, University of Nebraska-Lincoln, Lincoln, NE, USA \\ ${ }^{3}$ Department of Atmospheric Sciences, University of Washington, Seattle, WA, USA \\ *current address: Department of Geosciences, University of Arkansas, Fayetteville, AR, USA
}

Correspondence to: Q. Fu (qfuatm@gmail.com)

Received: 15 April 2013 - Published in Atmos. Chem. Phys. Discuss.: 5 June 2013

Revised: 8 September 2013 - Accepted: 9 September 2013 - Published: 14 October 2013

\begin{abstract}
Global drylands encompassing hyper-arid, arid, semiarid, and dry subhumid areas cover about 41 percent of the earth's terrestrial surface and are home to more than a third of the world's population. By analyzing observations for 1948-2008 and climate model simulations for 19482100 , we show that global drylands have expanded in the last sixty years and will continue to expand in the 21 st century. By the end of this century, the world's drylands (under a high greenhouse gas emission scenario) are projected to be $5.8 \times 10^{6} \mathrm{~km}^{2}$ (or 10\%) larger than in the 1961-1990 climatology. The major expansion of arid regions will occur over southwest North America, the northern fringe of Africa, southern Africa, and Australia, while major expansions of semiarid regions will occur over the north side of the Mediterranean, southern Africa, and North and South America. The global dryland expansions will increase the population affected by water scarcity and land degradations.
\end{abstract}

\section{Introduction}

Drylands are areas of land with low amounts of water in the soil, encompassing hyper-arid, arid, semiarid, and dry subhumid areas. Drylands occupy about 41 percent of the earth's terrestrial surface and are home to more than a third of the world's population (e.g., Mortimore et al., 2009). Knowledge of how anthropogenic climate change will affect the extent of global drylands is essential for water-resource and land-use management in these regions (e.g., Mortimore et al., 2009; Reynolds et al., 2007).

Drylands include desert, grassland and savanna woodland biomes. As one of the world's major ecosystems, the dry- lands live at the margin of sustainability, where moisture is scarce for all or part of the year (e.g., Mortimore et al., 2009). The ecosystems over drylands are fragile and sensitive to climate change (Reynolds et al., 2007; Solomon et al., 2007; Reed et al., 2012). Both observations and model simulations indicate that ongoing global warming will cause the earth's drylands to become drier (e.g., Solomon et al., 2007; Held and Soden, 2006; Seager et al., 2007; Overpeck ad Udall, 2010) but previous studies have focused on climate changes within drylands or specific types of drylands (e.g., semiarid regions) (Held and Soden, 2006; Seager et al., 2007; Overpeck ad Udall, 2010; Hulme, 1996; Huang et al., 2012). Here we examine the changes in the areal extent of drylands by analyzing observations for 1948-2008 and simulations for 1948-2100 from 27 global climate models participating in phase 5 of the Coupled Model Intercomparison Project (CMIP5) (Taylor et al., 2012). We show that global drylands have expanded in the last sixty years and will continue to expand in the 21st century. By the end of this century, the drylands under a high greenhouse gas emission scenario are projected to be $5.8 \times 10^{6} \mathrm{~km}^{2}$ (or $10 \%$ ) larger than the 1961-1990 climatology. Expansion of drylands associated with an increase in aridity as a result of climate change has a direct consequence on the desertification (i.e., land degradation in arid, semiarid, and dry subhumid areas), and is a central issue for sustainable development, especially in the face of population growth (Reynolds et al., 2007).

This paper is organized as follows. Section 2 describes the methods and data used in this study. The global dryland expansions and changes in aridity are presented in Sect. 3, followed by the discussions and summary in Sect. 4 . 


\section{Methods and data}

Dryland regions are commonly defined (e.g., Mortimore et al., 2009; Hulme, 1996; Middleton and Thomas, 1992) on the basis of the ratio of annual precipitation $(P)$ to annual potential evapotranspiration (PET); the latter represents the evaporative demand of the atmosphere. $P$ / PET is thus a quantitative indicator of the degree of water deficiency at a given location. Drylands are regions with $P /$ PET $<0.65$, which are further divided into hyperarid $(P /$ PET $<0.05)$, arid $(0.05<P /$ PET $<0.2)$, semiarid $(0.2<P /$ PET $<0.5)$, and dry subhumid (or subhumid for simplicity) $(0.5<P / \mathrm{PET}<0.65)$ regions (Mortimore et al., 2009; Hulme, 1996; Middleton and Thomas, 1992). We calculated PET using the Penman-Monteith algorithm (Maidment, 1993) that includes the effects of surface air temperature, humidity, solar radiation and wind. This algorithm is derived from physical principles and is superior to empirically based formulations that usually only consider the effect of temperature (Donohue et al., 2010; Dai, 2011; Sheffield et al., 2012). The PM algorithm was recommended by Food and Agriculture Organization (FAO) as the standard method to compute the PET (Allen et al., 1998).

\subsection{Instrumental data}

Two observed monthly temperature and precipitation data sets were used. We used multiple observational data sets to make sure that our results are robust and do not depend on the data set used. The first is the temperature and precipitation data set from 1948 to present developed by the Climate Prediction Center (CPC) (Fan and van den Dool, 2008; Chen et al., 2002). The second is the temperature and precipitation for 1900-2008 developed at the University of Delaware (UD) (Legates and Willmott, 1990a and b). Both data sets cover the global land areas at $0.5^{\circ} \times 0.5^{\circ}$ resolution. Though the UD data set started in 1900, the historical observations used for gridding are sparse or simply unavailable over many land areas, especially in the Southern Hemisphere during the first half of the 20th Century. Therefore, this study analyzed the period starting from 1948 when both CPC and UD data are available.

Because the two data sets employed a slightly different number of observations with different spatial interpolation methods, the climatology, e.g., for 1961-1990, from the two data sets is slightly different. We adjusted the UD temperature and precipitation so that they have the same monthly climatology as the CPC following Dai (2011) in order to focus on the temporal variations and long-term climate changes. Specifically, the temperature is adjusted according to

$$
\left[T_{\mathrm{UD}, \text { adj }}\right]_{\mathrm{Y}, \mathrm{M}}=\left(\left[T_{\mathrm{UD}}\right]_{\mathrm{Y}, \mathrm{M}}-\left[T_{\mathrm{UD}, \mathrm{clim}}\right]_{\mathrm{M}}\right)+\left[T_{\mathrm{CPC}, \mathrm{clim}}\right]_{\mathrm{M}},
$$

where $\left[T_{\mathrm{UD}}\right]_{\mathrm{Y}, \mathrm{M}}$ and $\left[T_{\mathrm{UD}, \mathrm{adj}}\right]_{\mathrm{Y}, \mathrm{M}}$ are the original and adjusted UD temperature for year " $\mathrm{Y}$ " and month "M", respectively. $\left[T_{\mathrm{UD}, \mathrm{clim}}\right]_{\mathrm{M}}$ and $\left[T_{\mathrm{CPC}, \mathrm{clim}}\right]_{\mathrm{M}}$ are the climatology of the UD and CPC temperature for 1961-1990 on month M. The precipitations of UD are adjusted according to

$$
\begin{aligned}
{\left[P_{\mathrm{UD}, \text { adj }}\right]_{\mathrm{Y}, \mathrm{M}}=} & {\left[P_{\mathrm{UD}}\right]_{\mathrm{Y}, \mathrm{M}} /\left(\left[P_{\mathrm{UD}, \mathrm{clim}}\right]_{\mathrm{M}}+0.01\right) } \\
& \times\left(\left[P_{\mathrm{CPC}, \mathrm{clim}}\right]_{\mathrm{M}}+0.01\right),
\end{aligned}
$$

where $\left[P_{\mathrm{UD}}\right]_{\mathrm{Y}, \mathrm{M}}$ and $\left[P_{\mathrm{UD}, \text { adj }}\right]_{\mathrm{Y}, \mathrm{M}}$ are the original and adjusted UD precipitation for year $\mathrm{Y}$ and month $\mathrm{M}$, respectively. $\left[P_{\mathrm{UD}, \mathrm{clim}}\right]_{\mathrm{M}}$ and $\left[P_{\mathrm{CPC} \text {,clim }}\right]_{\mathrm{M}}$ are the climatology of the UD and CPC precipitation for 1961-1990 on month M. We add $0.01 \mathrm{~mm}$ per month to the denominator to avoid dividing zero. These adjustments ensure that the UD data set has the same climatology of 1961-1990 as the CPC, but they do not affect the temporal variations and trends of the UD data sets. We chose to adjust the UD data set because they are not updated in real time but are several years behind, while the CPC data set is updated regularly in near-real time. Similar adjustments were used for merging different data sets (Dai et al., 2004) or developing the forcing data for land surface models (Sheffield et al., 2006).

\subsection{Reanalysis data}

To calculate the PET using the Penman-Monteith algorithm (Maidment, 1993; Allen et al., 1998), the surface air temperature, solar radiation, specific humidity and wind speed are needed. Due to scarce observations for specific humidity, solar radiations and wind speed, we chose to use these quantities from the global atmospheric reanalyses following previous studies (Sheffield et al., 2006; Dai, 2011, 2013). This study employed the solar radiation, specific humidity and wind speed data from the Global Land Data Assimilation System (GLDAS) (Rodell, et al., 2004), which is on half-degree resolution starting from 1948. The solar radiation in GLDAS was corrected based on two global radiation products during 1983-2000 (Sheffield et al., 2006). The wind and specific humidity in GLDAS, however, were directly disaggregated from the NCEP-NCAR reanalysis (Kalnay et al., 1996) to a $0.5^{\circ}$ resolution. We adjusted the wind and specific humidity in GLDAS to the observationally based climatology developed by the Climate Research Unit (CRU) of the University of East Anglia (New et al., 1999) following

$\left[V_{\mathrm{adj}}\right]_{\mathrm{Y}, \mathrm{M}}=[V]_{\mathrm{Y}, \mathrm{M}} /\left[V_{\text {clim }}\right]_{\mathrm{M}} \times\left[V_{\mathrm{CRU}, \mathrm{clim}}\right]_{\mathrm{M}}$,

where $[V]_{Y, M}$ and $\left[V_{\text {adj }}\right]_{Y, M}$ are the original and adjusted climate variables (humidity or wind speed) in GLDAS for year $\mathrm{Y}$ and month $\mathrm{M}$, respectively. $\left[V_{\mathrm{clim}}\right]_{\mathrm{M}}$ and $\left[V_{\mathrm{CRU}, \mathrm{clim}}\right]_{\mathrm{M}}$ are the 1961-1990 mean values of GLDAS and CRU, respectively. These adjustments ensure that the humidity and wind speed in GLDAS have the same climatology as the observations.

We also calculated PET using solar radiation, specific humidity and wind speed from the Twentieth Century Reanalysis (20CR) (Compo et al., 2011). The 20CR, extending back to 1871 , is the only reanalysis to span the 20th century. Ferguson and Villarini (2012) evaluated the temperature 
Table 1. A list of CMIP5 GCMs used in this study with a brief description. The historical run (1850-2005) and two future scenario (RCP4.5 and RCP8.5) runs (2006-2100) from each model are used. The first ensemble run is used if a model has multiple ensemble runs.

\begin{tabular}{|c|c|c|c|}
\hline & Model name & $\begin{array}{l}\text { Resolution } \\
\text { (lon by lat) }\end{array}$ & Origin \\
\hline 1 & BCC-CSM1.1 & $2.815 \times 2.815$ & Beijing Climate Center, China \\
\hline 2 & CanESM2 & $2.815 \times 2.815$ & Canadian Centre for Climate, Canada \\
\hline 3 & CCSM4 & $1.25 \times 0.9$ & National Center for Atmospheric Research, USA \\
\hline 4 & CESM1-BGC & $1.25 \times 0.9$ & National Center for Atmospheric Research, USA \\
\hline 5 & CESM1-CAM5 & $1.25 \times 0.9$ & National Center for Atmospheric Research, USA \\
\hline 6 & CMCC-CM & $0.75 \times 0.75$ & Centro Euro-Mediterraneo per i Cambiamenti, Italy \\
\hline 7 & CMCC-CMS & $1.875 \times 1.875$ & Centro Euro-Mediterraneo per i Cambiamenti, Italy \\
\hline 8 & CNRM-CM5 & $1.40 \times 1.40$ & Centre National de Recherches Meteorologiques, France \\
\hline 9 & CSIRO-Mk3.6 & $1.875 \times 1.875$ & Commonwealth Scientific and Industrial Research, Australia \\
\hline 10 & FGOALS-g2 & $2.815 \times 3.0$ & Institute of Atmospheric Physics, CAS, China \\
\hline 11 & GFDL-CM3 & $2.5 \times 2.0$ & Geophysical Fluid Dynamics Laboratory, USA \\
\hline 12 & GFDL-ESM2G & $2.5 \times 2.0$ & Geophysical Fluid Dynamics Laboratory, USA \\
\hline 13 & GFDL-ESM2M & $2.5 \times 2.0$ & Geophysical Fluid Dynamics Laboratory, USA \\
\hline 14 & GISS-E2-H & $2.5 \times 2.0$ & NASA Goddard Institute for Space Studies, USA \\
\hline 15 & GISS-E2-R & $2.5 \times 2.0$ & NASA Goddard Institute for Space Studies, USA \\
\hline 16 & HadGEM2-CC & $1.875 \times 1.25$ & Met Office Hadley Centre, UK \\
\hline 17 & HadGEM2-ES & $1.875 \times 1.25$ & Met Office Hadley Centre, UK \\
\hline 18 & INM-CM4 & $2.0 \times 1.5$ & Institute for Numerical Mathematics, Russia \\
\hline 19 & IPSL-CM5A-LR & $3.75 \times 1.875$ & Institut Pierre-Simon Laplace, France \\
\hline 20 & IPSL-CM5A-MR & $2.5 \times 1.25$ & Institut Pierre-Simon Laplace, France \\
\hline 21 & IPSL-CM5B-LR & $3.75 \times 1.875$ & Institut Pierre-Simon Laplace, France \\
\hline 22 & MIROC5 & $1.40 \times 1.40$ & Atmosphere and Ocean Research Institute, Japan \\
\hline 23 & MIROC-ESM & $2.815 \times 2.815$ & Japan Agency for Marine-Earth Science and Technology, Japan \\
\hline 24 & MIROC-ESM-CHEM & $2.815 \times 2.815$ & Japan Agency for Marine-Earth Science and Technology, Japan \\
\hline 25 & MPI-ESM-LR & $1.875 \times 1.875$ & Max Planck Institute for Meteorology, Germany \\
\hline 26 & MRI-CGCM3 & $1.125 \times 1.125$ & Meteorological Research Institute, Japan \\
\hline 27 & NorESM1-M & $2.5 \times 1.875$ & Norwegian Climate Centre, Norway \\
\hline
\end{tabular}

and precipitation data in the $20 \mathrm{CR}$ and identified spurious changes in the 1940s. They recommended restricting climate trend analyses to the second half century of the 20CR record. This study used the 20CR data starting from 1948. The radiation, specific humidity and wind speed in 20CR were statistically downscaled to $0.5^{\circ}$ resolution (Ramirez-Villegas and Jarvis, 2010). They were also adjusted to have the same climatology of 1961-1990 as the adjusted GLDAS data set.

To evaluate the observed changes in drylands, we calculated the PET and $P$ / PET using the precipitation and temperature from $\mathrm{CPC}$ or UD, and the specific humidity, solar radiations, and wind speed from GLDAS or 20CR for 1948-2008. Therefore, we have four sets of PET and $P$ / PET from observations (i.e., CPC \& GLDAS, CPC \& 20CR, UD $\&$ GLADS, UD \& 20CR). We use the PET and $P$ / PET derived from CPC and GLDAS in this study but test the sensitivity of our results to other data sets.

\subsection{CMIP5 data}

We used the output from 27 global climate models (Table 1) with specified historical anthropogenic and natural external forcings for 1948-2005 and with 21st century changes in greenhouse gases and anthropogenic aerosols following the Representative Concentration Pathway 8.5 (RCP8.5) and 4.5 (RCP4.5) for 2006-2100 (Taylor et al., 2012). The first ensemble run was used if a model has multiple ensemble simulations. Because the models have different spatial resolutions ranging from 0.75 to $3.75^{\circ}$ (Table 1), the simulated temperature, precipitation, solar radiation, specific humidity and wind speed were statistically downscaled to half-degree resolution (Ramirez-Villegas and Jarvis, 2010) to match that of observational data. The model results were also adjusted so that they have the same climatology of 1961-1990 as the observations. The modeled temperature anomalies relative to the 1961-1990 model climatology, for example, were firstly computed and then interpolated to half-degree resolution. The statistically downscaled values are the sum of the modeled anomalies at half-degree resolution and the observed temperature climatology during 1961-1990. Similar procedures were used to downscale other model variables (Ramirez-Villegas and Jarvis, 2010). This downscaling approach, therefore, reserves the temporal variations and trends in the models. 


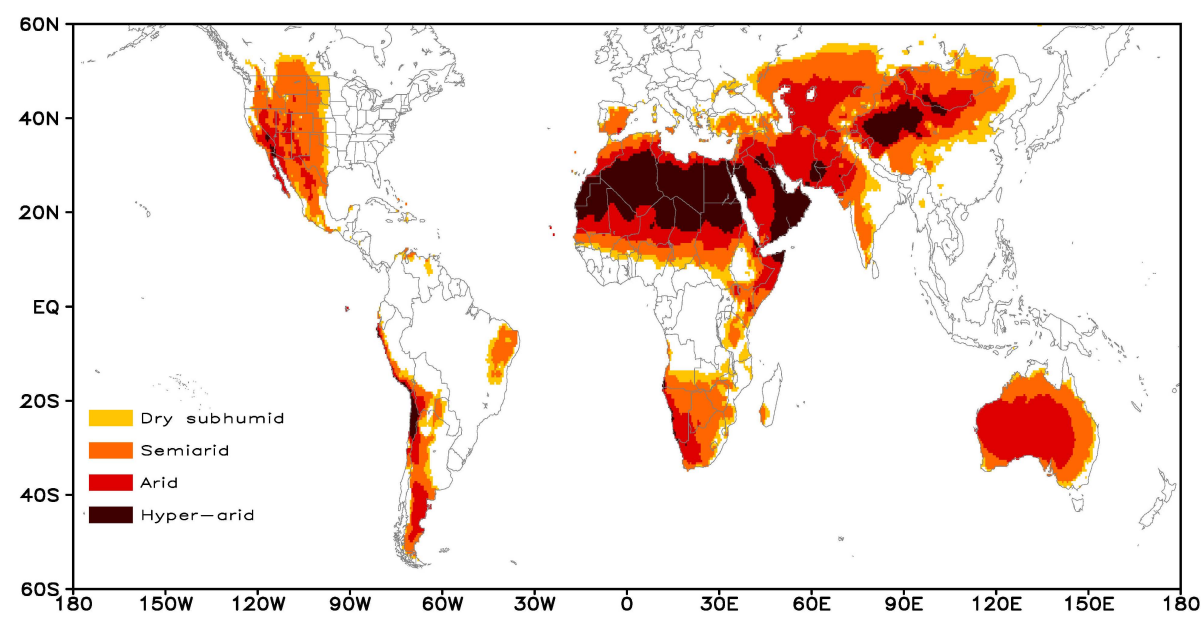

Fig. 1. Global distribution of drylands for 1961-1990 climatology derived from $P$ / PET ratio based on observations.

The ensemble mean of the 27 models is analyzed because the multi-model ensemble average is superior to the individual model (Pierce et al., 2009). This ensemble mean can be interpreted as our best estimate of climate responses to given external forcings because individual ensemble runs simulate random internal variations and contain errors associated with individual models. We should keep in mind, however, that natural fluctuations in climate, which cannot be predicted, are expected to occur, and will augment or reduce the magnitude of climate change due to anthropogenic forcing (Deser et al., 2012). Here we use the spread (one standard deviation) and/or consensus (more than $80 \%$ ) of the 27 models to measure the uncertainties associated with natural variations and model errors.

For the evaluation of temporal variations in the areal extent of drylands, a $15 \mathrm{yr}$ equal weight smoothing is applied to both model and observational data to remove year-to-year fluctuations. It was suggested that a $15 \mathrm{yr}$ smoothing is the optimal averaging windows for climate classifications (Fraedrich et al., 2001).

\section{Expansions of global drylands}

Figure 1 shows the global distribution of drylands, including the individual components for 1961-1990 climatology based on $P$ / PET derived from CPC and GLDAS, which agrees well with previous documentations (e.g., IIASA/FAO, 2003; Mortimore et al., 2009). The derived spatial distribution of hyper-arid, arid, and semiarid regions also matches well with surface vegetation types associated with these regions from the satellite measurements (Fig. 2). Note that the climatology of global dryland coverage for 1961-1990 from various observational and model data is the same as a result of the adjustments (Sect. 2) so that we can focus on the temporal variations and trends of the drylands.

\subsection{Dryland expansions}

Climate change associated with changes in precipitation and PET would lead to changes in aridity (i.e., $P$ / PET) and thus the areal extent of drylands. Figure 3 shows the time series of dryland areas, including the total and its individual components from both observations and models. The global drylands from observations have been expanding during the past $60 \mathrm{yr}$ (Fig. 3a). The area of global drylands of the past $15 \mathrm{yr}(1991-2005)$ is $\sim 2.4 \times 10^{6} \mathrm{~km}^{2}$ (or $4 \%$ ) larger than that during the 1950s. The areas of individual dryland components (except hyper-arid regions) show increases. The observed maximum (minimum) area of semiarid (arid) regions during 1970s is a result of large positive precipitation anomalies in Southern Hemisphere over Australia, Southern Africa, and Patagonia (Hulme, 1996), which led to a transition of arid to semiarid regions. Figure 4 indicates that the temporal variations of $T, P$, PET, and dryland areas are very similar based on various observational data sets.

An expansion of global drylands is also a robust feature in the simulations of 27 global climate models, though the rate is smaller than observations in last $60 \mathrm{yr}$ (Fig. 3). Because the observationally derived PET for 1948-2008 is well simulated by the models (Fig. 4c), the weaker expansion seen in the models is very likely caused by the differences in precipitation. Figure $4 \mathrm{~b}$ shows that the ensemble mean of the 27 models is able to capture the downward trends of the observed precipitation from the late 1940s to the early 1980s. However, the models simulated an increased precipitation after the early 1980s, while the observations show little noticeable trend.

Evidence from both observations and models shows that over the past few decades the tropics have widened (e.g., Fu et al., 2006; Hu and Fu, 2007; Lu et al., 2007; Seidel et al., 2008; Johanson and Fu, 2009; Zhou et al., 2011; Fu and Lin, 2011), which results in shifts in precipitation patterns 

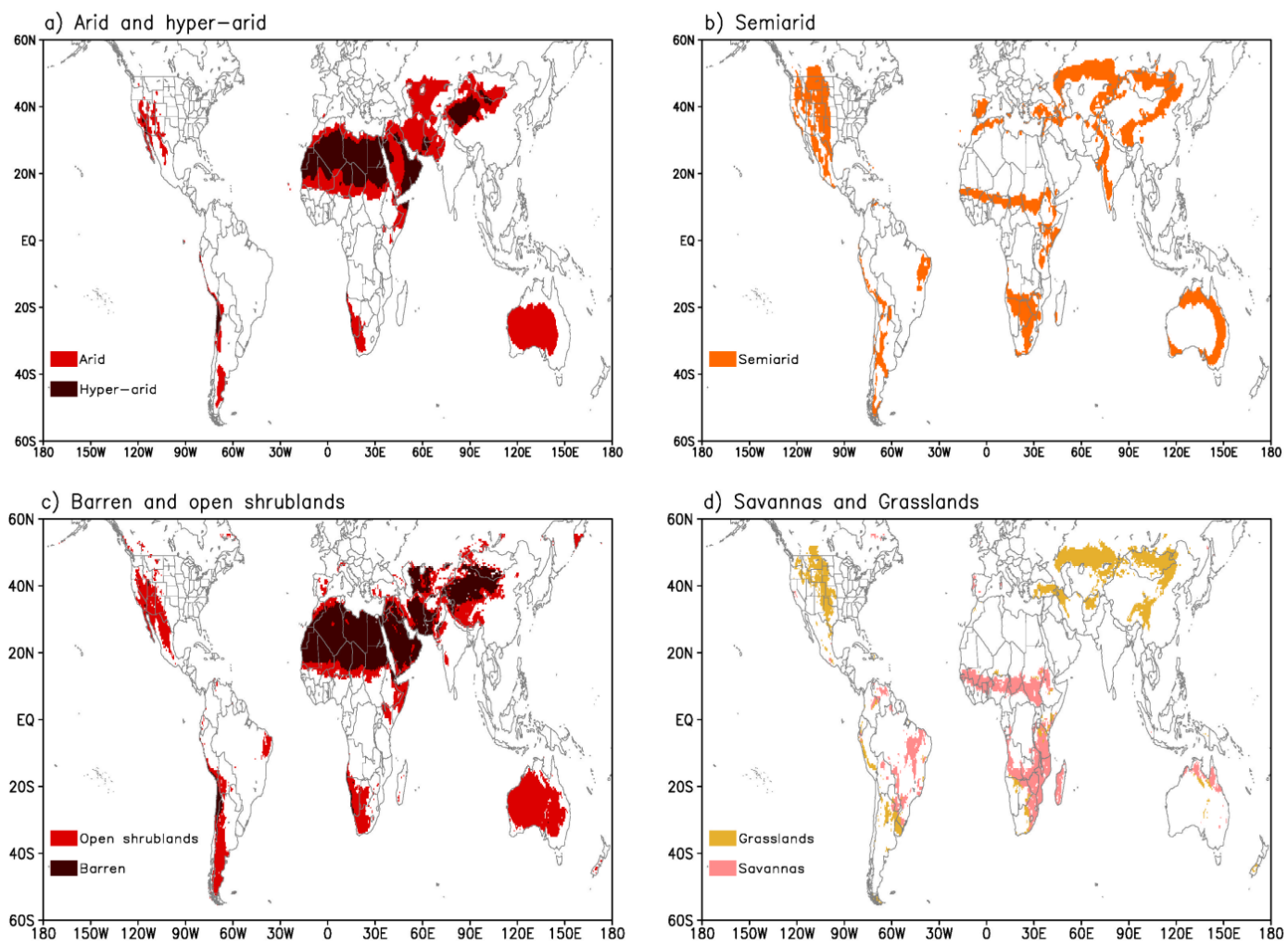

Fig. 2. Global distribution of (a) arid and hyper-arid and (b) semiarid regions derived from $P$ / PET ratio based on observations versus corresponding surface vegetation types in (c) and (d), respectively, from satellite Moderate-resolution Imaging Spectroradiometer (MODIS) observations (ISLSCP II MODIS (Collection 4, 2010) IGBP Land Cover, available online http://daac.ornl.gov/). On the lower left panel, the barren soil and open shrublands, respectively, are shown as dark red and red. On the lower right panel, the Savannas and Grasslands, respectively, are shown as pink and light yellow.

(Seidel et al., 2008), and especially a reduction of precipitation in the latitudes between subtropical dry zones and midlatitude precipitation belts (Zhou et al., 2011; Scheff and Frierson, 2012). Model-predicted expansion rates of the tropics, however, are significantly less than observations (Lu et al., 2007; Johanson and Fu, 2009), which could be a result of large natural variability, model deficiencies, and/or uncertainties in external forcings in models (Allen et al., 2012). Smaller modeled expansions of global drylands (Fig. 3) than observations would at least partly be caused by the underestimation of modeled tropical expansion. Precipitation over land is also strongly influenced by natural variability of sea surface temperature patterns (Schubert et al., 2009; Feng et al., 2011), which could largely contribute to the differences between models and observations (Dai, 2013).

Despite the differences between model and observations, the models are able to simulate the robust expansion of drylands (Fig. 3). The models also suggest a stronger trend in the first half of this century from both RCP8.5 and RCP4.5 than in the second half of the last century, followed by a continuing expansion in RCP8.5, but with little change in RCP4.5 after the 2050s. The global drylands in RCP8.5 (RCP4.5) are projected for 2071-2100 to increase in units of $10^{6} \mathrm{~km}^{2}$ by
$5.8 \pm 2.6(2.7 \pm 1.3)$ for the total, $1.3 \pm 1.2(0.6 \pm 0.6)$ for dry subhumid, $2.1 \pm 1.5(1.0 \pm 0.7)$ for semiarid, $1.8 \pm 1.3$ $(1.0 \pm 0.8)$ for arid, and $0.5 \pm 1.5(0.1 \pm 0.8)$ for hyper-arid regions, relative to 1961-1990. These increases correspond to relative increases of $10 \%(4 \%), 15 \%(7 \%), 10 \%(4 \%)$, $10 \%(5 \%)$, and $5 \%(1 \%)$, respectively. There is a broad consensus among climate models that global drylands will expand in the 21st century: of the 27 models for RCP8.5 (RCP4.5), expansions are seen in 26 (27) models for the total, 27 (24) for semiarid, 26 (22) for arid, and 22 (24) for dry subhumid regions, which are all more than $80 \%$ (i.e., 22 to 27 ) of the models. The exception is for hyper-arid regions: only 14 (15) of 27 models show an expansion. If slower rates in the last $60 \mathrm{yr}$ from models than observations (Fig. 3) were partly caused by model deficiencies, the model projections may underestimate the future expansion of global drylands.

The projected expansions of drylands are not homogeneous over the globe, and some occur in politically unstable regions. Figure 5 shows projected changes in drylands to drier (a) and wetter (b) types for 2071-2100 in RCP8.5 relative to 1961-1990. Major expansions of arid lands are projected over southwest North America, the northern fringe of Africa, southern Africa, and Australia. Expansions of arid 

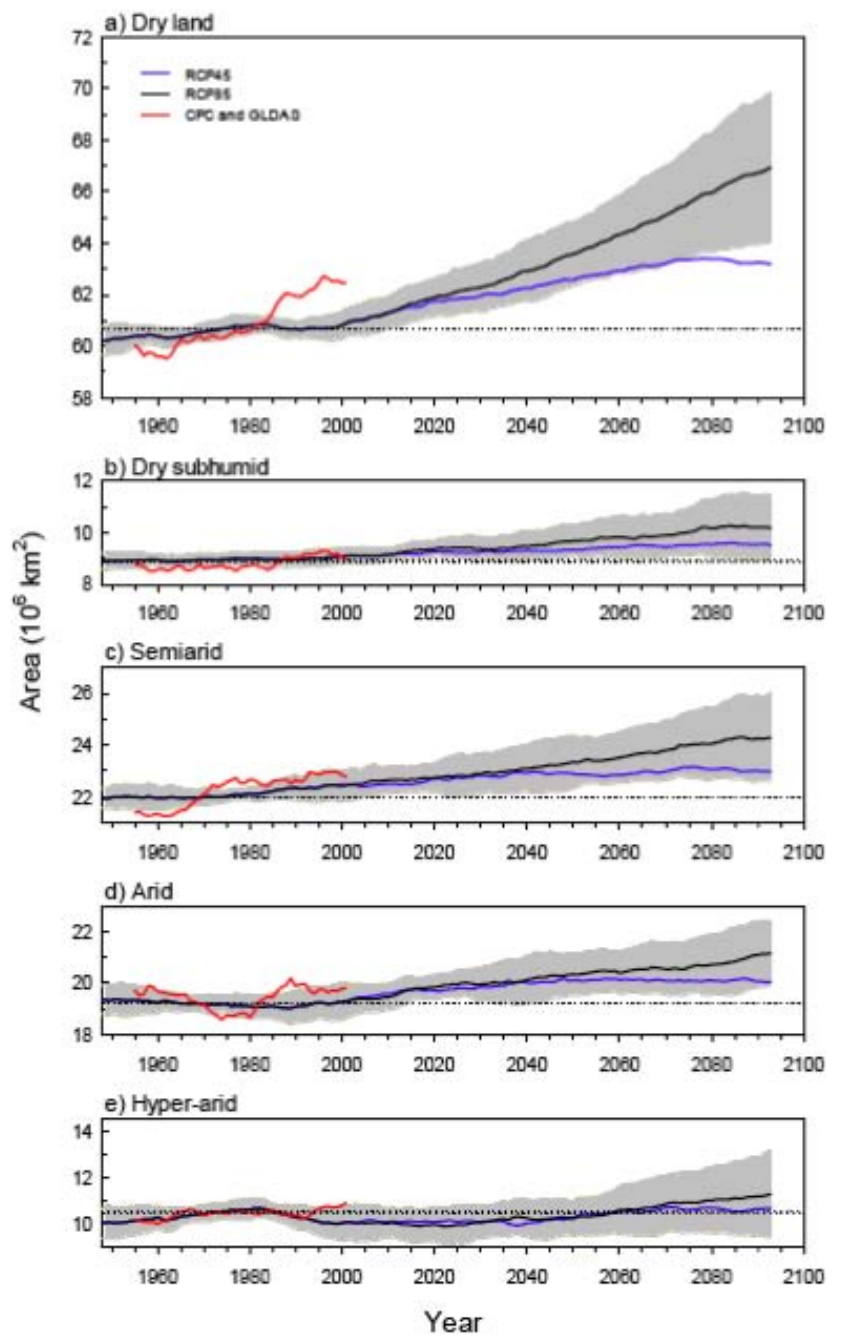

Fig. 3. Temporal variations in areal coverage of global drylands for (a) the total and individual components of (b) dry subhumid, (c) semiarid, (d) arid, and (e) hyper-arid regions, in units of $10^{6} \mathrm{~km}^{2}$. Thick black (blue) lines are the ensemble average of the 27 models from historical/RCP8.5 (RCP4.5) simulations. Dotted line shows the climatology of 1961-1990. The grey shading denotes one standard deviation of the 27 models from historical/RCP8.5 simulations. Red lines are for dryland areas based on observational data. A $15 \mathrm{yr}$ running smoothing was applied to emphasize the climate change.

regions are also seen in Afghanistan, Iran, Iraq, and Argentina. Major expansions of semiarid regions are projected over the north side of Mediterranean, southern Africa, and North and South America. Major expansions of hyper-arid areas will occur over northern Africa, parts of Saudi Arabia and Iraq, and southern Africa.

In southwest North America during 1961-1990 (Fig. 1), the arid lands occupied the Nevada, Arizona, southern California, southern Utah, and southwest New Mexico. By the end of this century, the arid regions are projected to expand
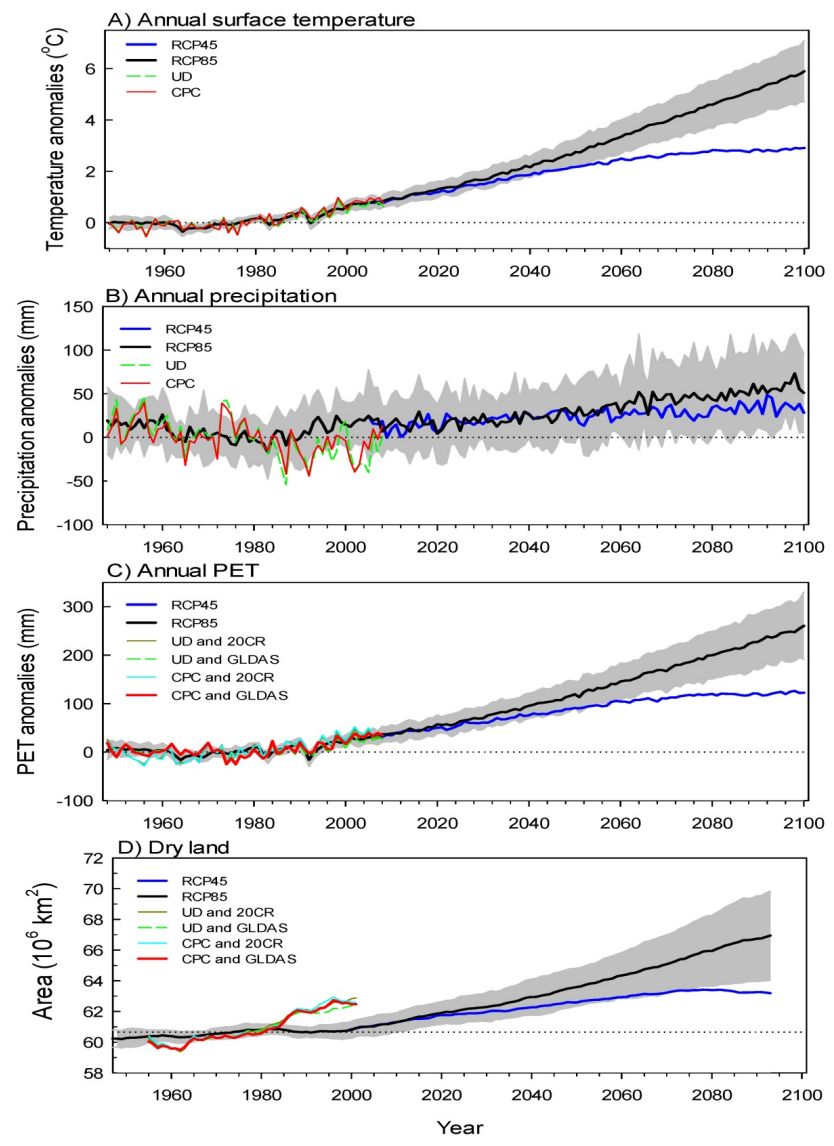

Fig. 4. Temporal variations of annual mean (a) surface air temperature, (b) precipitation, and (c) PET, averaged over land between $60^{\circ} \mathrm{N}$ and $60^{\circ} \mathrm{S}$, and (d) total area of global drylands. Thick black (blue) lines are the ensemble average of the 27 models from historical/RCP8.5 (RCP4.5) simulations. Dotted line shows the climatology of 1961-1990. The grey shading denotes one standard deviation of the 27 models from historical/RCP8.5 simulations. In (a) and (b), the observations from CPC (UD) data are shown as red (green dashed) lines. In (c) and (d), the observational results from combinations of UD or CPC, with 20CR or GLDAS indicate that the temperature and precipitation are from UD or CPC, and the solar radiation, humid and wind speed are from the 20th century reanalysis or GLDAS.

to occupy most of the New Mexico, western Texas and most of northern Mexico. The semiarid lands will also expand eastward by $2-3$ degrees of longitude in the Great Plains (Fig. 5a). In the Mediterranean region the semiarid climate is projected to expand to cover the edge of Black Sea, Greece, southern Italy and northern Spain. Over the northern fringe of Africa (northern coastal regions of Morocco, Algeria and Tunisia), the arid and hyper-arid climate is projected to expand into regions where the climate is currently semiarid. In southern Africa, the semiarid region is projected to expand northward and eastward while the arid climate is projected to cover most of the Namibia and majority of the Botswana. 

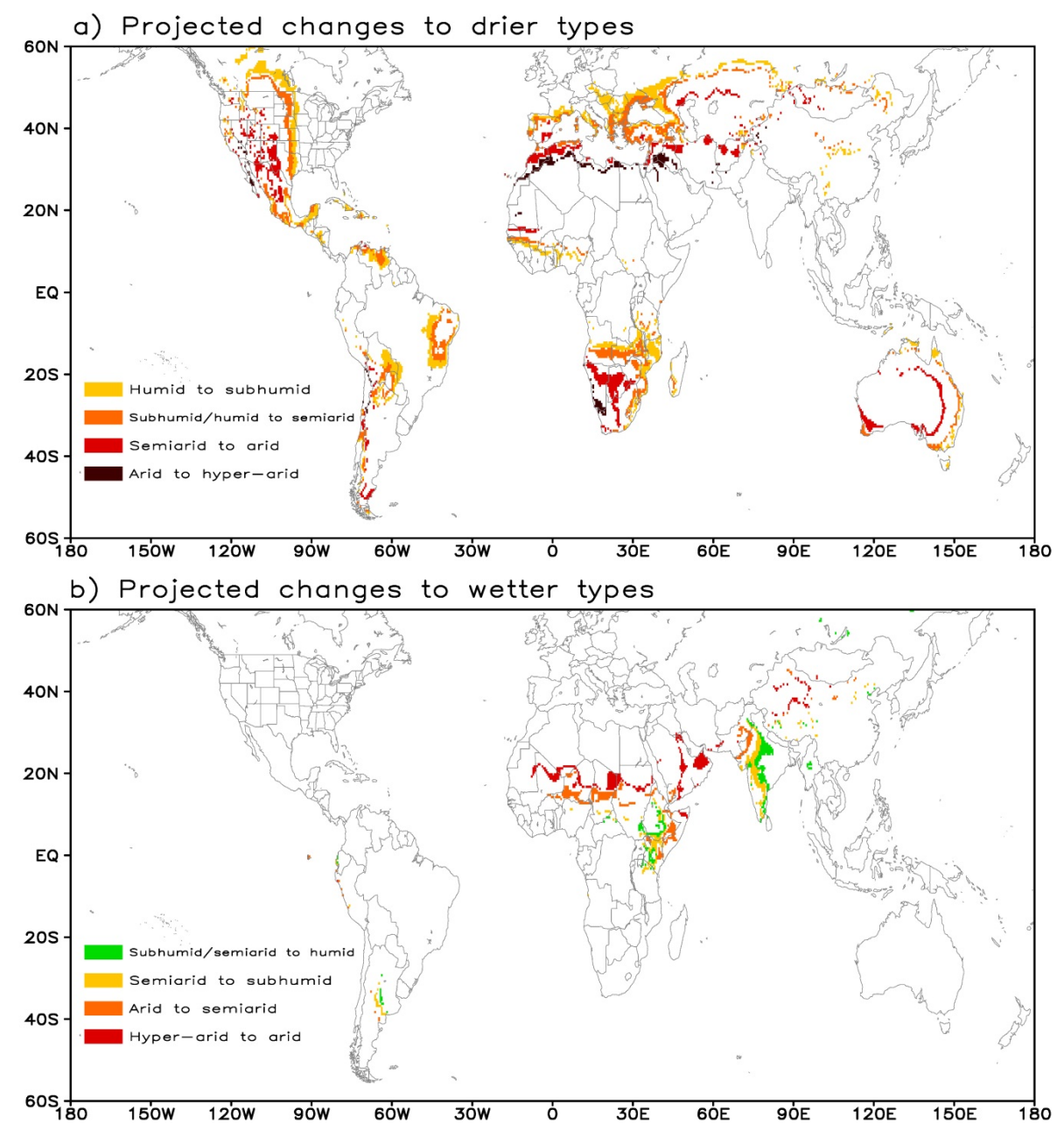

Fig. 5. (a) projected changes in coverage to drier types for 2071-2100 under scenario RCP8.5 relative to 1961-1990, and (b) same as (a) but to wetter types, based on the ensemble average of the 27 models.

Figure 6 is the same as Fig. 5a but for projected changes for which more than $80 \%$ of the models agree. By comparing these two figures, we see less confidence in projected dryland expansions over east Australia, China, Mongolia, and Kazakhstan. More than $80 \%$ of the models, however, agree on major projected expansions of drylands shown in Fig. 5a.

Besides expanding, the drylands in tropical Africa and India and part of northwest China are projected to shrink, suggesting reducing aridity in those regions (Fig. $5 b$ ). The retreat of hyper-arid (arid) to arid (semiarid) in the southern Sahara countries along with the expansions of hyper-arid and arid regions in the northern fringe of Africa indicates a poleward shift of northern African drylands. The areas with reducing aridity (Fig. 5b), however, are much smaller than areas with intensified aridity (Fig. 5a). Furthermore there is little consensus among the models (not shown) on the projected shrinking areas of drylands as a result of simulated internal variability and model uncertainty.

\subsection{Changes in global aridity}

Changes in global aridity are caused by changes in temperature through its impact on PET, and precipitation, which leads to the expansion of drylands. At the end of the 21 st century, the large increase of surface temperature (Fig. 7a) is largely responsible for a much enhanced PET throughout the global land (Fig. 7b) with large increases in Northern hemisphere mid- and high latitudes and North and South America, but less in Africa, Australia and India. Consistent with previous studies (Solomon et al., 2007), the projected precipitation (Fig. 7c) increases over most of Eurasia, tropical Africa and the middle and high-latitude North America but decreases in the subtropical regions, including areas near the Mediterranean Sea, southwestern North America, southern Africa and most of Australia and South America. The response of precipitation to global warming can be interpreted as a result of poleward expansion of the Hadley cell (Scheff and Frierson, 2012) and the "dry-get-drier" thermodynamic 


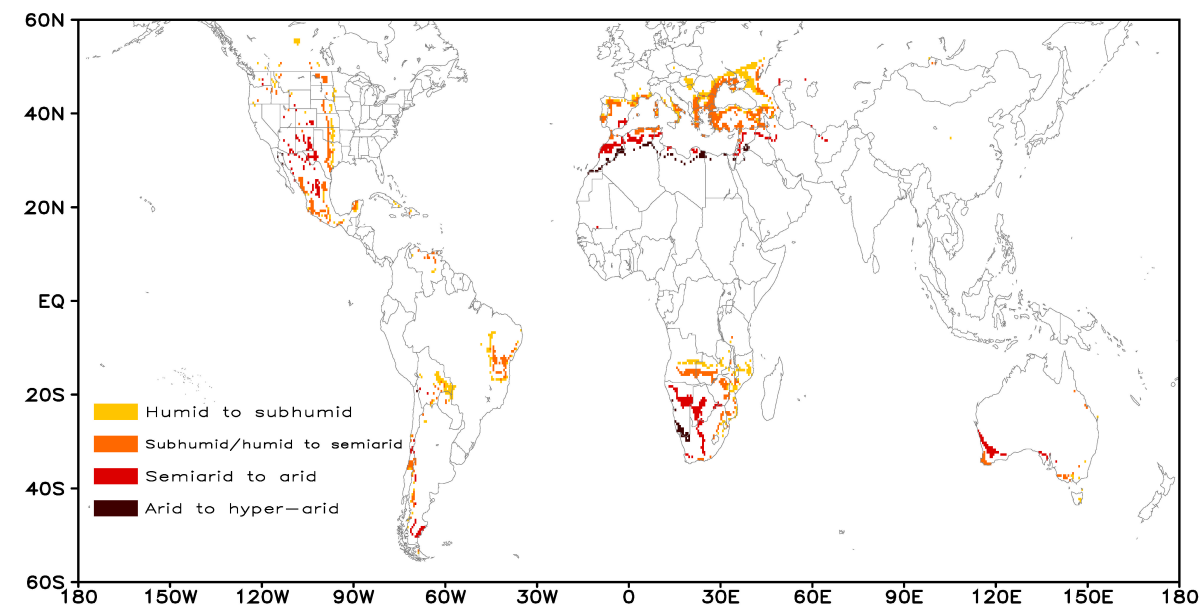

Fig. 6. Same as Fig. 5a but for projected area changes to drier types where more than $80 \%$ of the 27 models agree on the sign.
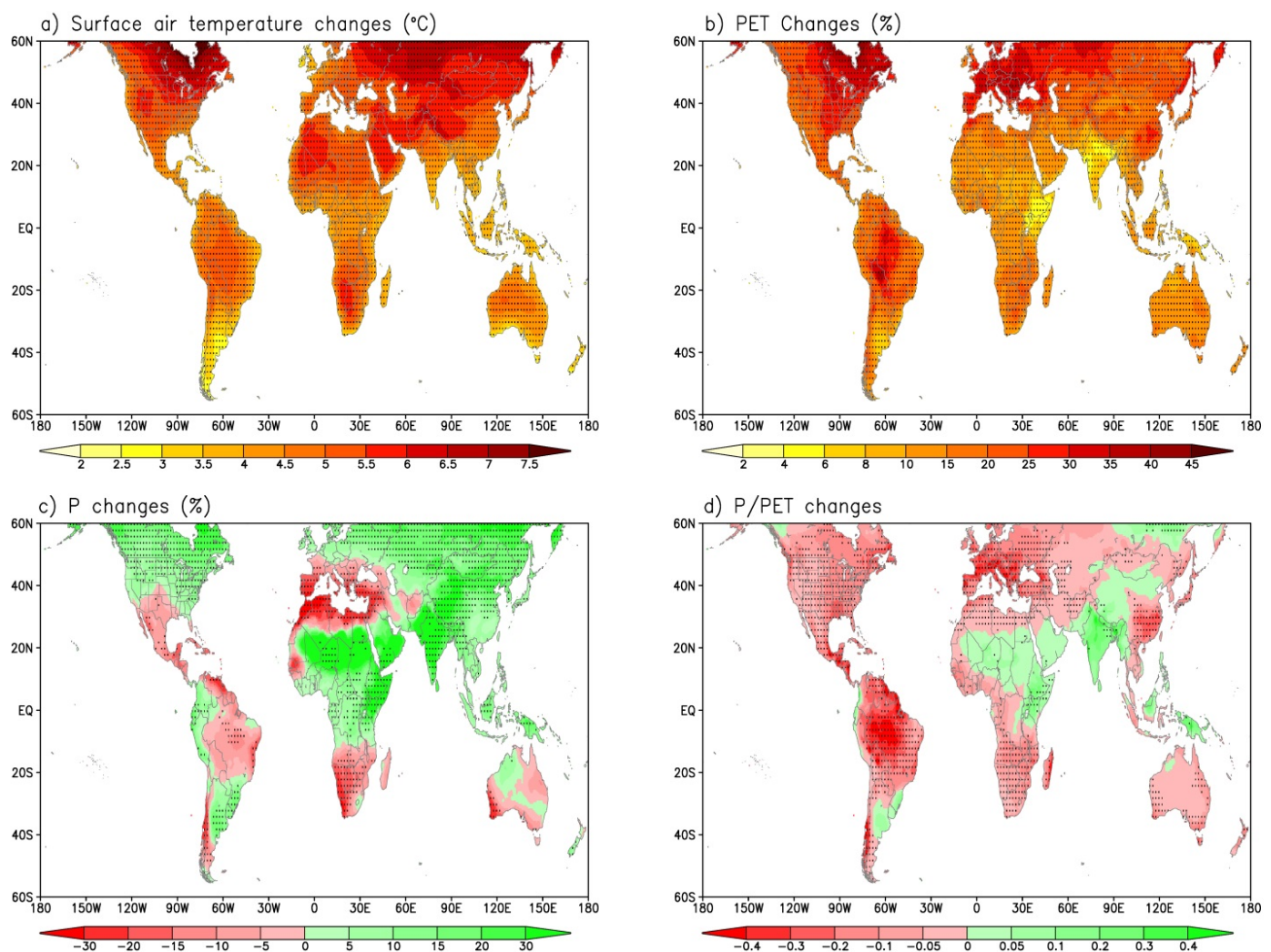

Fig. 7. Projected changes in (a) surface air temperature $\left({ }^{\circ} \mathrm{C}\right)$, (b) PET $(\%)$, (c) precipitation (\%), and (d) $P$ / PET for 2071-2100 relative to 1961-1990 under scenario RCP85 from 27 climate models. Grid points are stippled where more than $80 \%$ of these models agree on the sign.

mechanism (Held and Soden, 2006). The projected changes in precipitation and increases in PET collectively lead to the projected changes in $P$ / PET (Fig. 7d), showing decreases in most of the global land between $60^{\circ} \mathrm{N}$ and $60^{\circ} \mathrm{S}$ except India, northern China, eastern equatorial Africa and the southern Saharan regions, consistent with shrinking drylands in those regions but expansion in others (Fig. 5). It is noted that both precipitation and PET increase over most of Asia, leading to a week change in aridity except over the southeast of China, which will become much drier at the end of this century.

It is important to quantify the role of precipitation and PET in the $P$ / PET changes. We estimate the roles of the $P$ and 
a) $P / P E T$ changes caused by $P$ changes

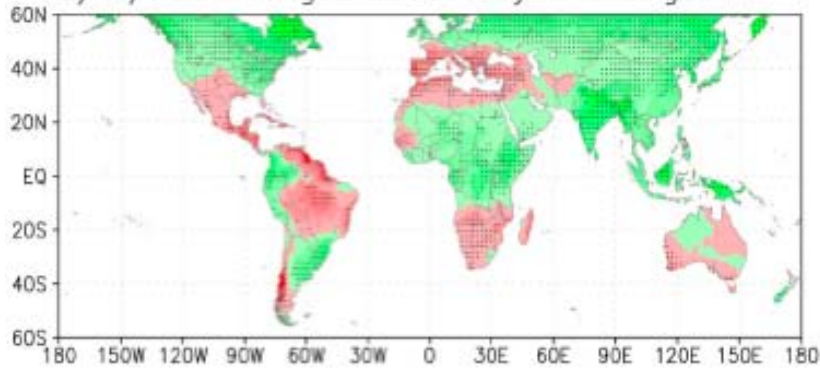

b) $P / P E T$ changes caused by PET changes

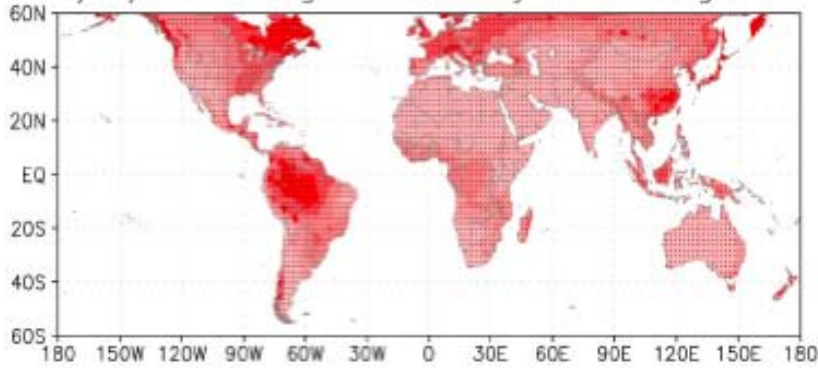

c) P/PET changes

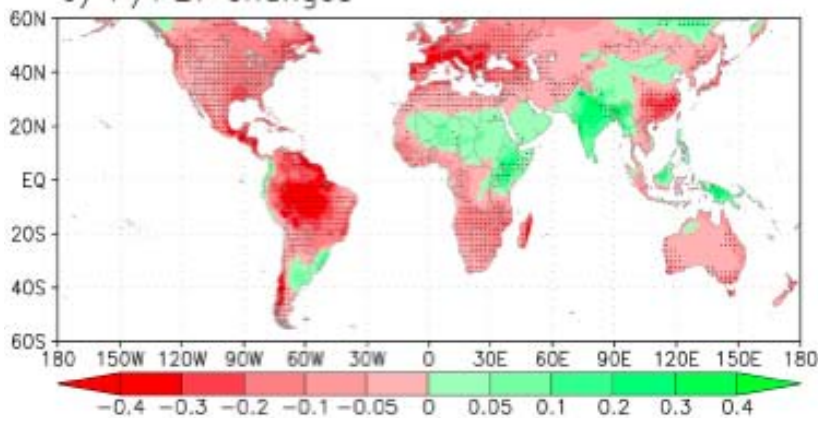

Fig. 8. Contributions of (a) precipitation and (b) PET to (c) projected changes in $P$ / PET for 2071-2100 relative to 1961-1990 under scenario RCP85 from 27 climate models. Grid points are stippled where more than $80 \%$ of these models agree on the sign.

PET in the $P$ / PET changes using

$\Delta\left(\frac{P}{\mathrm{PET}}\right)=\frac{1}{\mathrm{PET}} \Delta P-\frac{P}{\mathrm{PET}^{2}} \Delta \mathrm{PET}+\frac{P}{\mathrm{PET}^{3}}(\Delta \mathrm{PET})^{2}$,

where $\Delta\left(\frac{P}{\mathrm{PET}}\right)$ is the changes in $P$ / PET, $\frac{1}{P E T} \Delta P$ is the contribution of $P$ changes to $P$ / PET change, and the second and the third terms on the right-hand side are the contribution of PET changes to $P$ / PET changes. Figure 8 shows the changes in $P$ / PET (Fig. 8c or Fig. 7d) due to changes in precipitation (Fig. 8a) and PET (Fig. 8b). An increase in PET (Fig. 7b) leads to an increase in aridity (i.e., a decrease in $P$ /PET) (Fig. 8b) everywhere. The mixture of increase and decrease of $P$ (Fig. 7c) leads to mosaic changes in $P$ /PET (Fig. 8a). All together, the changes in PET and $P$ lead to an increase in aridity over majority of the global land between $60^{\circ} \mathrm{N}$ and $60^{\circ} \mathrm{S}$ (Fig. 8c).

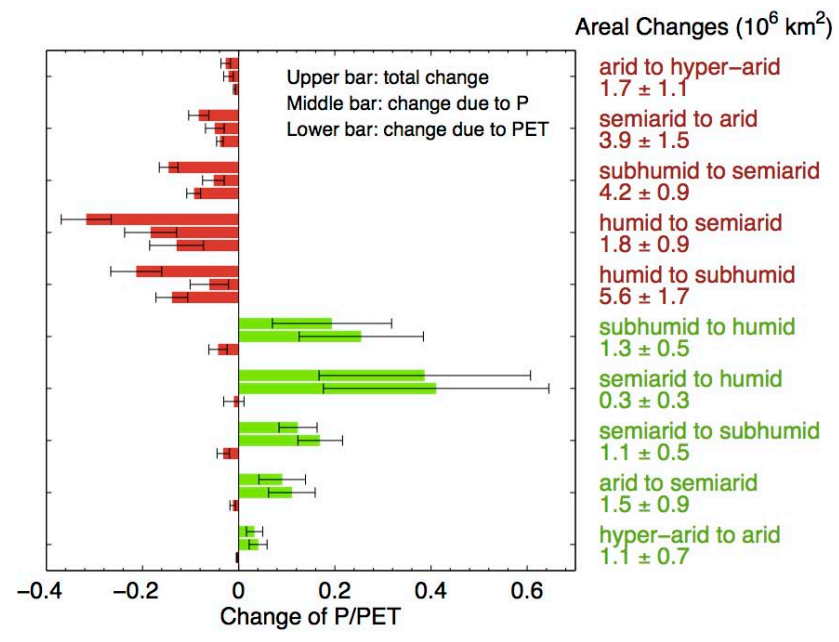

Fig. 9. Changes in $P$ / PET (upper bar) and contributions of precipitation (middle bar) and PET (lower bar) to $P$ / PET changes from 1961-1990 to 2071-2100 for RCP8.5, averaged over changed areas of drylands from 27 models. Error bars give the one standard deviation of the 27 models. The numbers on the right show the projected area changes.

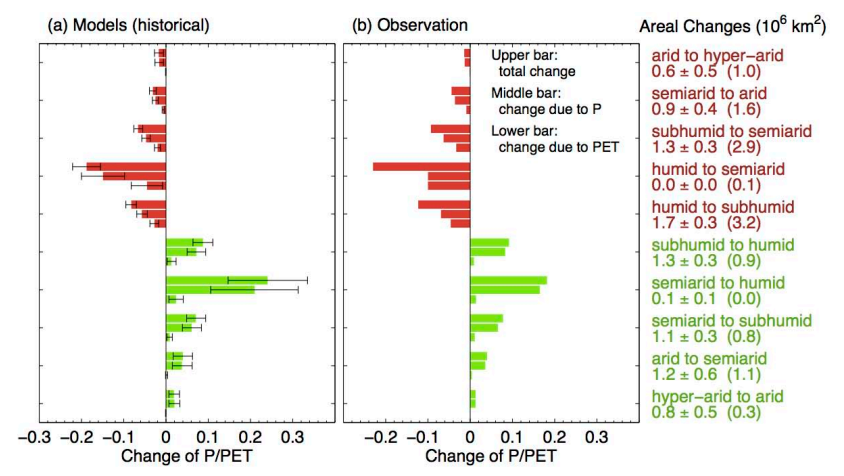

Fig. 10. Changes in $P$ / PET (upper bar) and contributions of precipitation (middle bar) and PET (lower bar) to $P$ / PET changes from 1948-1962 to 1991-2005, averaged over changed areas of drylands from (a) historical simulations and (b) observations. Error bars give the one standard deviation of the 27 models. The numbers on the right and those in parentheses show area changes from models and observations, respectively.

We also quantify the role of $P$ and PET in the $P$ /PET changes that lead to changes of drylands types. Figure 9 shows the changes in $P / \mathrm{PET}$ and the contributions from $P$ and PET, averaged over changed areas along with the projected area changes for RCP8.5. For areas projected to change to drier types, the increase in PET plays a dominant role in those from humid (dry subhumid) to dry subhumid (semiarid) while the precipitation decrease becomes more important for other changes to drier regions. The regions with reducing aridity are all controlled by increasing precipitation (see green bars in Fig. 9). 

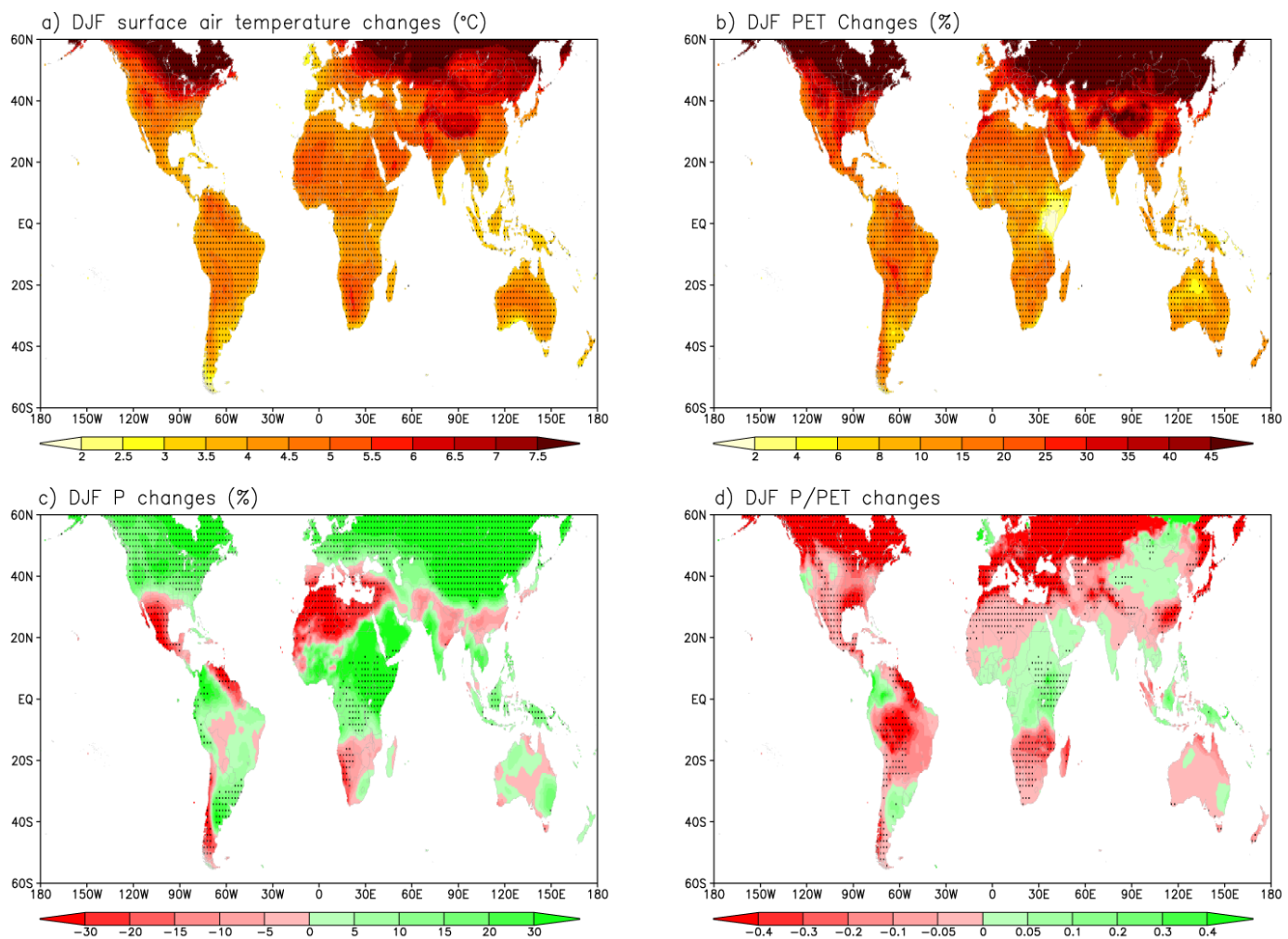

Fig. 11. Same as Fig. 7 but for the season of December-January-February.
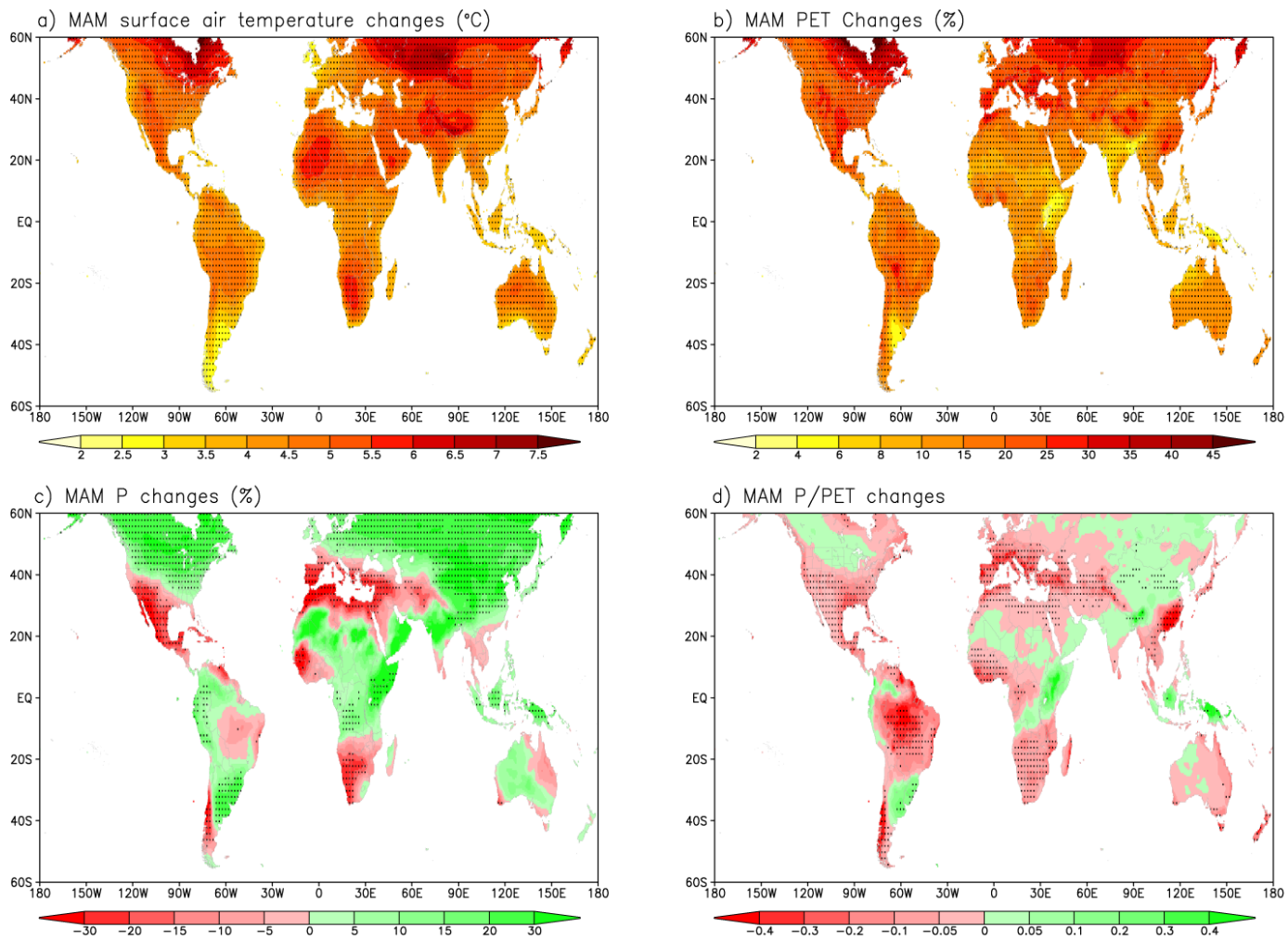

Fig. 12. Same as Fig. 7 but for the season of March-April-May. 

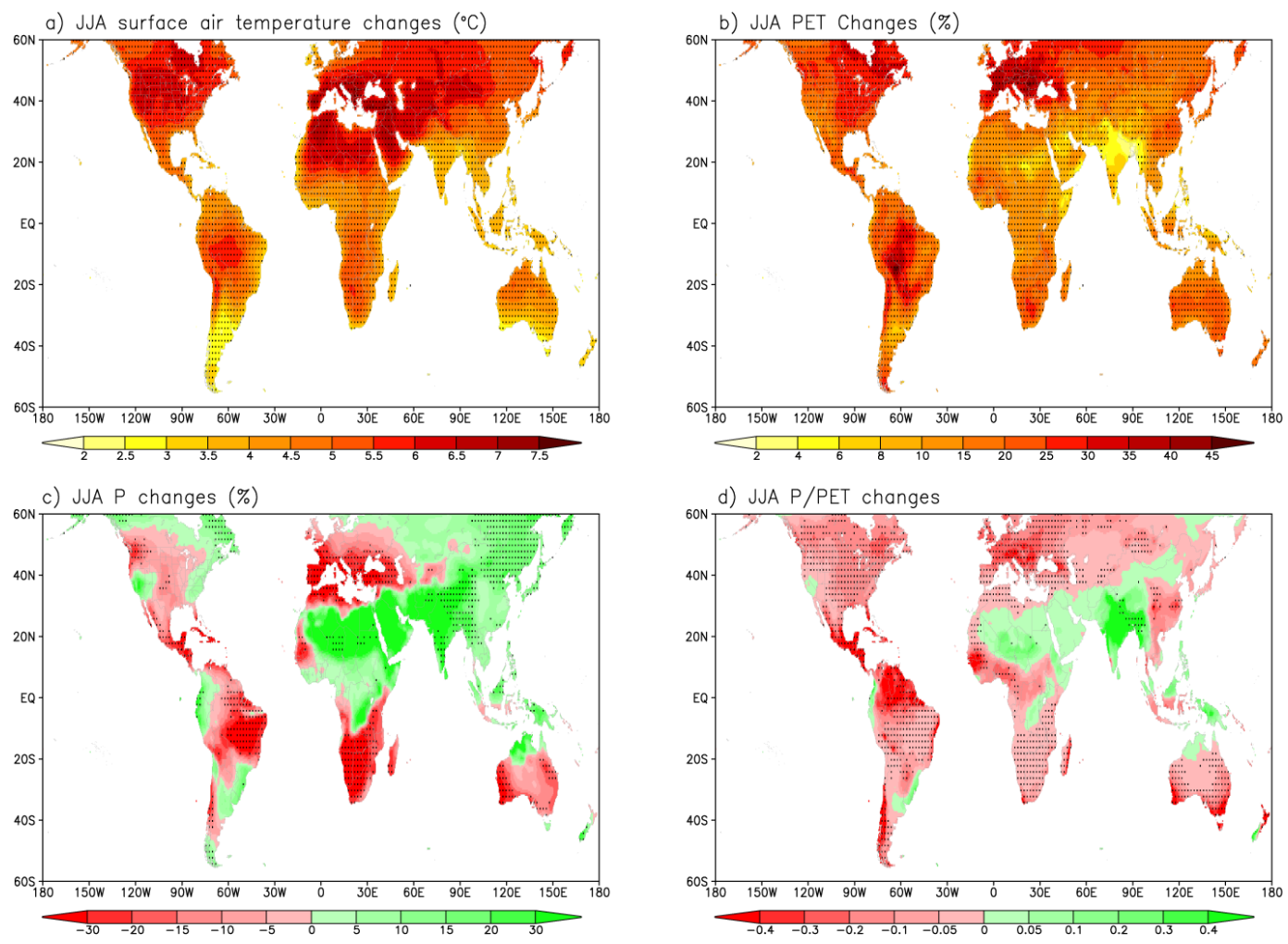

Fig. 13. Same as Fig. 7 but for the season of June-July-August.
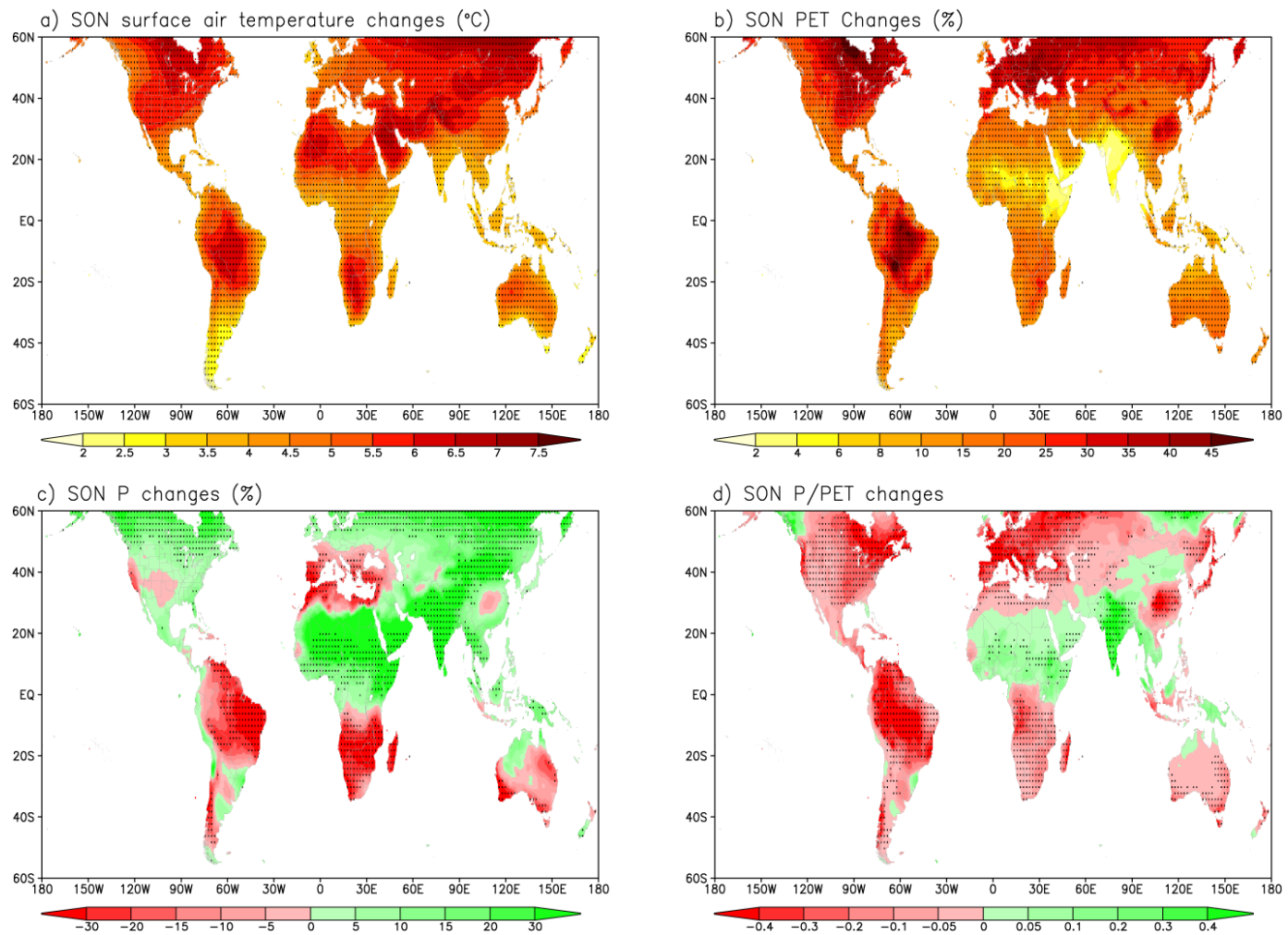

Fig. 14. Same as Fig. 7 but for the season of September-October-November. 
Figure 10 is the same as Fig. 9 except for results from the historical runs (a) and observations (b) for changes of 1991-2005 relative to 1948-1962. The important difference from the future projection is that the decrease of precipitation dominates the decrease in $P$ / PET that led to the expansion of drylands. This is because greenhouse gas-induced warming during the past sixty years is much smaller than what is projected to occur at the end of the 21 st century, while anthropogenic forcings considered in historical simulations such as black carbon aerosols, increases in tropospheric ozone, and stratospheric ozone depletion favor the expansion of the subtropical dry zone (Johanson and Fu, 2009; Allen et al., 2012). The role of precipitation from observations (Fig. 10b) is similar to that from historical simulations. It is noted that the dryland expansion in the last sixty years (i.e., 1991-2005 versus 1948-1962) from models is only $0.35 \times 10^{6} \mathrm{~km}^{2}$, which is much smaller than $2.4 \times 10^{6} \mathrm{~km}^{2}$ from observations. This difference could be due to large natural SST variations in last $60 \mathrm{yr}$ which were not captured by the models (Schubert et al., 2009; Feng et al., 2011; Dai, 2013) as well as the underestimation of the Hadley cell expansion. The models also do not simulate the enhanced wintertime warming over the mid- and high-latitude Northern Hemisphere continents during the later 20th century (e.g., Huang et al., 2012), which is largely caused by natural variability (Wallace et al., 2012). This may also be partly responsible for the differences.

The change in annual mean aridity is responsible for the changes in the dryland areas that are defined by the ratio of annual precipitation to annual PET. It would be also useful to show how the aridity changes in different seasons for other applications. Figures 11-14 are the same as Fig. 7 but for December-February, March-May, July-August, and September-November seasons.

\section{Discussions and summary}

The increase of PET and changes in precipitation patterns under a warming climate are leading to an increase in global aridity and expansion of global drylands, and thus an increase in the population affected by water scarcity (Milesi et al., 2010). Extensive land use and other human activities may further amplify these changes (Reynolds et al., 2007). Another important consequence of these changes is the desertification, i.e., the land degradation in arid, semiarid, and dry subhumid regions resulting from various factors, including climatic variations and human activities (UNCCD, 1994). The effect of dust aerosols on climate (e.g., Huang et al., 2010) will thus also likely become more evident. Severe land degradation is already present in 10 to $30 \%$ of drylands (Reynolds et al., 2007), which is likely to expand substantially in the face of climate change and population growth. Such changes could result in fundamental shifts in ecosystems and human settlements. Paleoclimate records indicate that climate change and increased aridity played a key role in the collapse of Mayan culture in Central America (Haug et al., 2003) and Tiwanaku civilization in the Andes (Binford et al., 1997). The recent persistent drought and increasing aridity in the southwestern US have witnessed higher mortality of trees, more bark-beetle outbreaks, more wildfires, and a reduction of forest productivity in the region (Williams et al., 2012). The rising temperature, increasing aridity, and expanding drylands along with extensive land uses could herald major social challenges and risks that would exacerbate regional tensions (Jones, 2011), which accentuates the urgent need to develop proactive planning and adaptation strategies for global drylands.

In this study, we analyze the change of global aridity and dryland expansions in terms of $P$ / PET using various observational data sets for 1948-2008, along with 27 climate model simulations from the CMIP5 for 1948-2100. We show that global drylands have expanded in the last sixty years with observed rates much faster than simulations, and will continue to expand in the 21 st century. By the end of this century, the world's drylands, under a high greenhouse gas emission scenario (RCP8.5), are projected to be $5.8 \times 10^{6} \mathrm{~km}^{2}$ (or $10 \%$ ) larger than in the 1961-1990 climatology. The major expansion of arid regions will occur over southwest North America, the northern fringe of Africa, southern Africa, and Australia, while major expansions of semiarid regions will occur over the north side of the Mediterranean, southern Africa, and North and South America. It is also shown that most of the global land between $60^{\circ} \mathrm{N}$ and $60^{\circ} \mathrm{S}$ except India, northern China, eastern equatorial Africa and the southern Saharan regions will become significantly drier. Expansion of global drylands associated with an increase in aridity will increase the population affected by water scarcity and land degradations.

Acknowledgements. We thank D. L. Hartmann, J. M. Wallace and Q. Hu for useful discussions and comments on the manuscript. This study is in part supported by the National Basic Research Program of China (2012CB955303), NSF Grant AGS-1103316, and USDA Cooperative Research Project NEB-38-088.

Edited by: X. Liu

\section{References}

Allen, R. G., Pereira, L. S., Raes, D., and Smith, M.: Crop evapotranspiration: guidelines for computing crop water requirements, FAO irrigation and drainage paper, 56, 1998.

Allen, R. J., Sherwood, S. C., Norris, J. R., and Zender, C. S.: Recent Northern Hemisphere tropical expansion primarily driven by black carbon and tropospheric ozone, Nature, 485, 350-354, 2012.

Binford, M. W., Kolata, A. L., Brenner, M., Janusek, J. W., Seddon, M. T., Abbott, M., and Curtis, J. H.: Climate variation and the rise 
and fall of an Andean civilization, Quarternary Res., 47, 235248, 1997.

Chen, M., Xie, P., Janowiak, J. E., and Arkin, P. A.: Global land precipitation: a 50-yr monthly analysis based on gauge observations, J. Hydrometeorol., 3, 249-266, 2002.

Compo, G. P., Whitaker, J. S., Sardeshmukh, P. D., Matsui, N., Allan, R. J., Yin, X., Gleason Jr., B. E., Vose, R. S., Rutledge, G., Bessemoulin, P., Broennimann, S., Brunet, M., Crouthamel, R. I., Grant, A. N., Groisman, P. Y., Jones, P. D., Kruk, M. C., Kruger, A. C., Marshall, G. J., Maugeri, M., Mok, H. Y., Nordli, O., Ross, T. F., Trigo, R. M., Wang, X. L., Woodruff, S. D., and Worley, S. J.: The twentieth century reanalysis project, Q. J. Roy. Meteorol. Soc., 137, 1-28, 2011.

Dai, A.: Increasing drought under global warming in observations and models, Nature Clim. Change, 3, 52-58, 2013.

Dai, A., Trenberth, K. E., and Qian, T.: A global dataset of Palmer drought severity index for 1870-2002: relationship with soil moisture and effects of surface warming, J. Hydrometeorol., 5, 1117-1130, 2004.

Dai, A. G.: Characteristics and trends in various forms of the Palmer drought severity index during 1900-2008, J. Geophys. Res., 116, D12115, doi:10.1029/2010JD015541, 2011.

Deser, C., Knutti, R., Solomon, S., and Phillips, A. S.: Communications of the role of natural variability in future North America Climate, Nature Clim. Change, 2, 775-779, 2012.

Donohue, R. J., McVicar, T. R., and Roderick, M. L.: Assessing the ability of potential evaporation formulations to capture the dynamics in evaporative demand within a changing climate, J. Hydrol., 386, 186-197, 2010.

Fan, Y. and van den Dool, H.: A global monthly land surface air temperature analysis for 1948-present, J. Geophys. Res., 113, D01103, doi:10.1029/2007JD008470, 2008.

Feng, S., Hu, Q., and Oglesby, R. J.: Influence of Atlantic sea surface temperatures on persistent drought in North America, Clim. Dynam., 37, 569-586, 2011.

Ferguson, C. R. and Villarini, G.: Detecting inhomogeneities in the twentieth century reanalysis over the central United States, J. Geophys. Res., 117, D05123, doi:10.1029/2011JD016988, 2012.

Fraedrich, K., Gerstengarbe, F. W., and Werner, P. C.: Climate shifts during the last century, Climatic Change, 50, 405-417, 2001.

Fu, Q. and Lin, P.: Poleward shift of subtropical jets inferred from satellite-observed lower stratospheric temperatures, J. Climate, 24, 5597-5603, 2011.

Fu, Q., Johason, C. M., Wallace, J. M., and Reichler, T.: Enhanced mid-latitude tropospheric warming in satellite measurements, Science, 312, p. 1179, 2006.

Haug, G. H., Gunther, D., Peterson, L. C., Sigman, D. M., Hughen, K. A., and Aeschlimann, B.: Climate and the collapse of Maya civilization, Science, 299, 1731-1735, 2003.

Held, I. M. and Soden, B. J.: Robust responses of the hydrological cycle to global warming, J. Climate, 19, 5686-5699, 2006.

$\mathrm{Hu}$, Y. and Fu, Q.: Observed poleward expansion of the Hadley circulation since 1979, Atmos. Chem. Phys., 7, 5229-5236, doi:10.5194/acp-7-5229-2007, 2007.

Huang, J., Minnis, P., Yan, H., Yi, Y., Chen, B., Zhang, L., and Ayers, J. K.: Dust aerosol effect on semi-arid climate over Northwest China detected from A-Train satellite measurements, Atmos. Chem. Phys., 10, 6863-6872, doi:10.5194/acp-10-68632010, 2010.
Huang, J., Guan, X., and Ji, F.: Enhanced cold-season warming in semi-arid regions, Atmos. Chem. Phys., 12, 5391-5398, doi:10.5194/acp-12-5391-2012, 2012.

Hulme, M.: Recent climatic change in the world's drylands, Geophys. Res. Lett., 23, 61-64, 1996.

Johanson, C. M. and Fu, Q.: Hadley cell expansion: model simulations versus observations, J. Climate, 22, 2713-2725, 2009.

Jones, N.: Heating up tensions, Nature Clim. Change, 1, 327-329, 2011.

Kalnay, E., Kanamitsu, M., Kistler, R., Collins, W., Deaven, D., Gandin, L., Iredell, M., Saha, S., White, G., Woollen, J., Zhu, Y., Chelliah, M., Ebisuzaki, W., Higgins, W., Janowiak, J., Mo, K. C., Ropelewski, C., Wang, J., Leetmaa, A., Reynolds, R., Jenne, R., and Joseph, D.: The NCEP/NCAR 40-year reanalysis project, B. Am. Meteorol. Soc., 77, 437-471, 1996.

Legates, D. R. and Willmott, C. J.: Mean seasonal and spatial variability in gauge-corrected, global precipitation, Int. J. Climatol., 10, 111-127, 1990a.

Legates, D. R. and Willmott, C. J.: Mean seasonal and spatial variability in global surface air temperature, Theor. Appl. Climatol., 41, 11-21, 1990b.

Lu, J., Vecchi, G. A., and Reichler, T.: Expansion of the Hadley cell under global warming, Geophys. Res. Lett., 34, L06805, doi:10.1029/2006GL028443, 2007.

Maidment, D. R.: Handbook of Hydrology, McGraw-Hill, New York, 1993.

Middleton, N. J. and Thomas, D. S. G.: UNEP: World atlas of desertification, Edward Arnold, Sevenoaks, 1992.

Milesi, C., Samanta, A., Hashimoto, H., Kumar, K. K., Ganguly, S., Thenkabail, P. S., Srivastava, A. N., Nemani, R. R., and Myneni, R. B.: Decadal variations in NDVI and food production in India, Remote Sensing, 2, 758-776, 2010.

Mortimore, M.: Dryland Opportunities, IUCN, Gland, Switzerland, HED, London, UK and UNDP, New York, USA, 2009.

New, M., Hulme, M., and Jones, P. D.: Representing twentiethcentury space-time climate variability, Part I: Development of a 1961-90 mean monthly terrestrial climatology, J. Climate, 12, 829-856, 1999.

Overpeck, J. and Udall, B.: Dry times ahead, Science, 328, 16421643, 2010.

Pierce, D. W., Barnett, T. P., Santer, B. D., and Gleckler, P. J.: Selecting global climate models for regional climate change studies, $\mathrm{P}$. Natl. Acad. Sci. USA, 106, 8441-8446, 2009.

Ramirez-Villegas, J. and Jarvis, A.: Downscaling global circulation model outputs: the delta method decision and policy analysis working paper No. 1, International Center for Tropical Agriculture, CIAT, Cali, Colombia, 2010.

Reed, S. C., Coe, K. K., Sparks, J. P., Housman, D. C., Zelikova, T. J., and Belnap, J.: Changes to dryland rainfall result in rapid moss mortality and altered soil fertility, Nature Clim. Change, 2, 752-755, 2012.

Reynolds, J. F., Stafford Smith, D. M., Lambin, E. F., Turner, B. L., Mortimore, M., Batterbury, S. P. J., Downing, T. E., Dowlatabadi, H., Fernandez, R. J., Herrick, J. E., Huber-Sannwald, E., Jiang, H., Leemans, R., Lynam, T., Maestre, F. T., Ayarza, M., and Walker, B.: Global desertification: building a science for dryland development, Science, 316, 847-851, 2007.

Rodell, M., Houser, P. R., Jambor, U., Gottschalck, J., Mitchell, K., Meng, C. J., Arsenault, K., Cosgrove, B., Radakovich, J., 
Bosilovich, M., Entin, J. K.,Walker, J. P., Lohmann, D., and Toll, D.: The global land data assimilation system, B. Am. Meteorol. Soc., 85, 381-394, 2004.

Seager, R., Ting, M., Held, I., Kushnir, Y., Lu, J., Vecchi, G., Huang, H. P., Harnik, N., Leetmaa, A., Lau, N. C., Li, C., Velez, J., and Naik, N.: Model projections of an imminent transition to a more arid climate in southwestern North America, Science, 316, 11811184, 2007.

Scheff, J. and Frierson, D.: Twenty-first-century multimodel subtropical precipitation decline are mostly midlatitude shifts, J. Climate, 25, 4330-4347, 2012.

Schubert, S., Gutzler, D., Wang, H., Dai, A., Delworth, T., Deser, C., Findell, K., Fu, R., Higgins, W., Hoerling, M., Kirtman, B., Koster, R., Kumar, A., Legler, D., Lettenmaier, D., Lyon, B., Magana, V., Mo, K., Nigam, S., Pegion, P., Phillips, A., Pulwarty, R., Rind, D., Ruiz-Barradas, A., Schemm, J., Seager, R., Stewart, R., Suarez, M., Syktus, J., Ting, M., Wang, C., Weaver, S., and Zeng, N.: A USCLIVAR project to assess and compare the responses of global climate models to drought-related SST forcing patterns: overview and results, J. Climate, 22, 5251-5272, 2009.

Seidel, D. J., Fu, Q., Randel, W. J., and Reichler, T. J.: Widening of the tropical belt in a changing climate, Nat. Geosci., 1, 21-24, 2008.

Sheffield, J., Goteti, G., and Wood, E. F.: Development of a 50-yr high-resolution global dataset of meteorological forcings for land surface modeling, J. Climate, 19, 3088-3111, 2006.

Sheffield, J., Wood, E. F., and Roderick, M. L.: Little change in global drought over the past, $60 \mathrm{yr}$, Nature, 491, 435-438, 2012.
Solomon, S., Qin, D., Manning, M., Chen, Z., Marquis, M., Averyt, K. B., Tignor, M., and Miller, H. K.: Climate Change, 2007: The Physical Science Basis, Cambridge Univ. Press, Cambridge, 2007.

Taylor, K. E., Stouffer, R. J., and Meehl, G. A.: An overview of CMIP5 and the experiment design, B. Am. Meteorol. Soc., 93, 485-498, 2012.

UNCCD (United Nations Convention to Combat Desertification), U. N. Doc. A/A C. 241/27, 33 I. L. M. 1328, United Nations, 1994.

Wallace, J. M., Fu, Q., Smoliak, B. V., Lin, P., and Johanson, C. M.: Simulated versus observed patterns of warming over the extratropical Northern Hemisphere continents during the cold season, P. Natl. Acad. Sci. USA, 109, 14337-14342, 2012.

Williams, A. P., Allen, C. D., Macalady, A. K., Griffin, D., Woodhouse, C. A., Meko, D. M., Swetnam, T. W., Rauscher, S. A., Seager, R., Grissino-Mayer, H. D., Dean, J. S., Cook, E. R., Gangodagamage, C., Cai, M., and McDowell, N. G.: Temperature as a potent driver of regional forest drought stress and tree mortality, Nature Clim. Change, 3, 292-297, doi:10.1038/NCLIMATE1693, 2012.

Zhou, Y. P., Xu, K. M., Sud, Y. C., and Betts, A. K.: Recent trends of the tropical hydrological cycle inferred from global precipitation climatology project and international satellite cloud climatology project data, J. Geophys. Res., 116, D09101, doi:10.1029/2010JD015197, 2011. 